From Exclusion to Inclusion: the Glasgow Magdalene Institution, an Instrument of Social Control in the Nineteenth Century

De l'exclusion vers l'inclusion: la Glasgow Magdalene Institution, instrument de contrôle social au dix-neuvième siècle.

\title{
Christian Auer
}

\section{(2) OpenEdition}

\section{Journals}

Electronic version

URL: http://journals.openedition.org/rfcb/5129

DOI: $10.4000 /$ rfcb.5129

ISSN: 2429-4373

\section{Publisher}

CRECIB - Centre de recherche et d'études en civilisation britannique

\section{Electronic reference}

Christian Auer, «From Exclusion to Inclusion: the Glasgow Magdalene Institution, an Instrument of Social Control in the Nineteenth Century ", Revue Française de Civilisation Britannique [Online], XXIV-4 I 2019, Online since 25 November 2019, connection on 27 November 2019. URL : http:// journals.openedition.org/rfcb/5129; DOI : 10.4000/rfcb.5129

This text was automatically generated on 27 November 2019.

\section{cc) (i) $8 \odot$}

Revue française de civilisation britannique est mis à disposition selon les termes de la licence Creative Commons Attribution - Pas d'Utilisation Commerciale - Pas de Modification 4.0 International. 


\title{
From Exclusion to Inclusion: the Glasgow Magdalene Institution, an Instrument of Social Control in the Nineteenth Century
}

\author{
De l'exclusion vers l'inclusion: la Glasgow Magdalene Institution, instrument de \\ contrôle social au dix-neuvième siècle.
}

\section{Christian Auer}

\section{Introduction}

1 Questioning the notion of social control, an inherently dynamic process more than a static concept, primarily means studying the mechanisms, methods and strategies through which a society manages to establish, secure and preserve social stability and cohesiveness. The title of this paper explicitly refers to the Glasgow Magdalene Institution as an instrument of social control, which seems to imply that the institution that was created in the early 1860s was only one constituent of a more comprehensive strategy aimed at controlling a category of the population, prostitutes, that did not comply with the rules or the norms established by society and who were seen as representing a potential threat to the political, sanitary and moral stability of the social structure ${ }^{1}$. The following passage, extracted from the Glasgow Magdalene Institution's annual report of 1870 , seems to show that the directors of the Institution were perfectly conscious of their essential role as protectors of social stability:

The directors of the GMI [...] desire to acknowledge, with gratitude to God, the amount of good accomplished through the instrumentality of the Homes, which in the past year have been kept full; a state of matters, which they believe, has been owing to the wholesome enforcement of the Police Act against street solicitation and improper houses. This much needed repressive action on the part of our civic authorities has had the effect of partially protecting the virtuous, and making the practice of vice more difficult; whilst at the same time the experience of the past 
year's work has proved that it has led to a desire on the part of many to be delivered from a life of evil. ${ }^{2}$

\section{Prostitution in mid-Victorian Britain}

2 Before analysing the strategies that were implemented by the Institution it is necessary to briefly examine how prostitution was perceived in mid-Victorian Britain. When one mentions prostitution in the context of nineteenth century Britain one is faced with a double paradox: on the one hand a society that showed violent hostility towards the prostitute, seen, to quote Judith Walkowitz, both as "an object of fascination and disgust" 3 and as the "highly visible symbol of the social dislocation attendant upon the industrial era"; yet, most Victorians were reluctant to legislate in the matter. ${ }^{5}$ As the following comment, written by an observer who tried to assess the number of prostitutes plying their trade during the Glasgow Fair, tends to suggest, the term prostitute could apply to any woman whose behaviour or lifestyle did not comply with the norms:

3 Saw 94 prostitutes, also a large number of millworkers, scarcely distinguishable from prostitutes in their conduct. Saw 5 young prostitutes squatting on the grass in a very immoral manner; also one couple lying on the grass. (We speak confidently of the purpose, because a policeman on the Green assured us ... that no woman went to the Green after a certain hour, save for that purpose). ${ }^{6}$

William Tait, a surgeon at the Lock Hospital of Edinburgh, who in 1842 published the results of an inquiry into prostitution, considered that "the term prostitute is always employed to designate a person who habitually follows the course of conduct implied in successive acts of prostitution". ${ }^{7}$ Prostitution was generally considered as being the result of voluntary choice and few Victorians were clear-sighted enough to attribute prostitution to unfavourable social circumstances. The following comment, written by the journalist William Greg, did not correspond to what most people thought at the time:

"The first and perhaps the largest class of prostitutes are those who may fairly be said to have had no choice on the matter [...] the prostitutes who spring from this class are clearly the victims of circumstances, and therefore must [...] be allowed to be objects of the most unalloyed compassion". ${ }^{8}$

Numerous were those who considered that venereal diseases were a natural punishment ordained by divine justice. The following graphic description, extracted from one of the Lectures on Female Prostitution by Ralph Wardlaw, who was a minister in Glasgow, is particularly telling:

The disease [...] is absolutely terrific. Its effects are, - extensive, severe, and loathsome ulcerations; the destruction of the eye-sight, and of the palate and tonsils; the rotting of the flesh from the bones; the exfoliation of the bones themselves, till the whole frame becomes a mass of living corruption, from which the eye, though filled with the tear of pity, turns away in sickening disgust. [...] I wish to fill you with loathing of the loathsome effect, that you may loath with a deeper loathing the more loathsome cause. ${ }^{9}$

6 The Contagious Diseases Act, voted on June 20 1864, represented the first real attempt to control prostitution in Great Britain. The Act, which was aimed at protecting the army and the navy from venereal diseases, allowed the police to ask women suspected of being prostitutes to have compulsory checks for venereal disease. ${ }^{10}$ If the women were found to be suffering from sexually transmitted diseases they were placed in a 
Lock hospital until cured. Although Glasgow was a garrison town the law was never applied there because the town had developed its own system of regulation and control of prostitution.

\section{The Glasgow system}

7 The Glasgow system, as it was called, relied on the close cooperation of three different institutions, the police, the Lock Hospital and the Magdalene Institution. The Glasgow Police Acts of 1843, 1862 and 1866 allowed the police to close brothels and to arrest and imprison women caught soliciting: "Every prostitute, or nightwalker loitering in any road or street court, or common stair, or importuning passengers for the purpose of prostitution shall be liable to a fine of 40 shillings or 14 days imprisonment". ${ }^{11}$ Diseased prostitutes were treated in the Lock hospital; as the surgeon of the hospital, Alexander Patterson, indicated to the parliamentary commission in 1882, the prostitutes could leave the hospital if they wanted to interrupt their treatment. The cornerstone of the Glasgow System was the Glasgow Magdalene Institution. The Institution had been created for "the Repression of vice, and the Reformation for penitent Females". ${ }^{12}$ The Institution's purposes were "to provide temporary homes for Females who have strayed from the paths of virtue [...] and who are willing to return to them, and similar refuge or other protection to females who may be in imminent danger of being led astray". ${ }^{13}$ The women admitted to the institution were not professional prostitutes but young women or girls - half of them were under twenty years of age - who had occasionally resorted to prostitution to support themselves. The authorities of the Institution considered that prostitution was a real plague that threatened the moral balance of society. In the report of 1862 prostitution was described as the "Social Evil", "the monster evil", "the social sore", "the terrible scourge", " the great social plague", "the giant sin" or "the Evil". ${ }^{14}$ The report of 1865 concluded that " Rooted in the vitals of society - suffered to grow through apathy on the one hand, and indifference or connivance on the other - the 'SOCIAL EVIL' disgraces the land, and calls for every effort to subdue it, reclaim its victims, and protect those who are in danger". ${ }^{15}$

Strict discipline was an integral part of the system put in place in the institution:

9 Punishment is viewed by our Society chiefly as a means to an end - that of discouraging vicious practices which leave their ruined victims very unlikely subjects of reformation, and which, moreover, if unchecked, are sure to find new victims to fill up the vacant space left by any old ones who have been rescued and reformed [...] punishment is simply our most direct and efficacious method of prevention. ${ }^{16}$

Inmates could in theory leave the institution if they wanted to: "It should be explained that the Matrons have no power, nor do they ever attempt to detain girls against their will. Every inmate is received on her voluntary application". ${ }^{17}$

\section{The Glasgow Magdalene Institution's annual reports}

11 After this brief presentation of the Glasgow Magdalene Institution, I would now like to turn my attention to the Institution's annual reports since these documents provide essential information about the ideological foundations of the Institution's discourse and about the way the directors of the Institution perceived their role and mission in society. Special attention will be paid to the former inmates' letters that were inserted 
at the end of the reports. How did the women that had left the Institution perceive the process of rehabilitation they had been subjected to? What practical and ideological influence did the Institution exert on these women? The former inmates' letters provide some answers to these questions.

The women committed themselves to keeping in touch with the institution for at least six months after they had left; if they encountered a problem, they were supposed to contact the institution for help or advice. Thus the process of moral rehabilitation went on after the two years the women generally spent in the institution. ${ }^{18}$ The reports indicate that the former inmates wrote regularly, but it seems that it was the matrons who took the initiative of writing as numerous inmates' letters start with an apology for not having written earlier. The following is a typical example: "I received your kind and welcome letter some time ago. You will be thinking me very careless in not answering your kind letter, but you will have to excuse me as I have been very busy". ${ }^{19}$ The letters systematically started with the inmates mentioning their present situation, "I like my place very well", ${ }_{20}$ "I am very comfortably situated", ${ }_{21}$ "I am coming on very well and like my place well". ${ }^{22}$ Here is one typical example taken from one of the letters published in the report of 1878: "beautiful weather", "pleasant music", "pleasant evening", "very nice piano", "pleasant fireside", "magnificent river", ${ }^{23}$ are but a selection of the numerous positive comments of the letter. The inmates would never fail to mention the time they had spent at the institution and the knowledge they had acquired there and not surprisingly the comments were always favourable and sometimes even dithyrambic." It is now I can bless that day that God sent me to the Home. It shall be in my heart and mind till I go to my grave the many blessed lessons I was taught by you and the dear gentlemen of the house". ${ }^{24}$ The lessons that had been learned seemed to have been completely assimilated: "While I am performing my duties around the house, I very often remember your instructions which are fresh in my memory". ${ }^{25}$ The women never forgot to specify that they constantly thought of the supervisors and their former friends; some of them even experienced intense nostalgia: "Oh, how do I often wish I was back at Lochburn once more, with all my kind friends" ${ }^{26}$ Some women even implied that their stay at the institution had been a kind of rebirth; they assimilated the institution to a new home or a new family and sometimes mentioned that they wished to go back to pay a visit to the supervisors. "Dear Mother, for I cannot call you anything else, as you have acted a mother's part over $m e^{\text {"27 }}$ or "I will never forget you, for you were a mother to me and you have handed me over to another mother". ${ }^{28}$ The link that had been established between these women and their supervisors or teachers transcended the simple relationship between pupil and master. The institution and its staff had replaced an absent family, the directors taking up the role of the paternal figure and the female staff taking up the role of the maternal figure.

One fundamental point requires close examination, and that is the profound religious dimension of all the letters. Before analysing some of the prominent aspects as regards that particular point it might be useful to note, as Tom Devine has pointed out, that " religious values continued to remain central to the ethos of Victorian Scotland". ${ }^{29}$ Olive Checkland, in a book about philanthropy in Victorian Scotland, has the following comment:

14 The Scotland of Victoria's reign saw a remarkable phenomenon, namely the attempt by the Church of Scotland and the other churches in Scotland to stay the tide of secularism and to recall the nation to God and to his worship. In this the 
philanthropists (both clerical and lay) were the driving force. By an extraordinary range of initiatives they sought to resist this incipient secularism of the industrial age and to create, perhaps in a somewhat renovated form, a life in which the Christian religion was the principal part. ${ }^{30}$

Needless to say, the Glasgow Magdalene Institution played its part in the process. Thus, it should not come as a surprise to see these women mention in very explicit terms the fundamental part religion and God played in their current lives. "I am always thinking of you and all the ladies, and girls. Oh, that they would all give their hearts to the Saviour, who is standing with melted heart and open hands to receive them". ${ }^{31}$ Life was nothing but a long passage sown with suffering and sin: "it was God my Father, and your Father, that brought me to you, and then He brought me to Jesus our blessed Saviour, and there I will ask God to keep me till death takes me away from this world of sin and misery". ${ }^{32}$ One had to endure the ordeals of earthly life with stoicism: "as we go through this world we sometimes find many difficulties, and we have just got to make the best of it". ${ }^{33}$ But there was definitely hope in the beyond: "Sooner or later we must part, but hope to meet in that lovely home above, to be with Christ; which is far better". ${ }^{34}$ Religion had a purifying function; it helped to surmount ones' darker impulses: "I don't feel any evil passion getting the same as I used to have, because when I feel any temper, I just say - Lord, give me a sweet temper, and that helps me greatly". ${ }^{35}$ The letter of an inmate who had emigrated to the province of New Brunswick in Canada seems to testify to the success of the proselytizing process:

There is a reformation going on out here under the name of the Dutchers Temperance Reformers, and they are doing splendid work in rescuing souls from a drunkard's death and grave. [...] We hope that this institution will continue as it has begun, going forth conquering and to conquer. ${ }^{36}$

Some of the letters constituted a real encouragement to emigration and would probably have delighted all those who thought that emigration was the panacea for solving the problem of overpopulation in Scotland. The following is an extract of a letter sent from Adelaide in Australia:

Any young woman can get from 25 to 30 shillings a week. I have not regretted of coming to this colony. I would advise any young woman to come out here; they would do much better than at home. I wish you could advise A - P - to come out here; I think it would be the best thing ever that ever she could do; she would be away from all temptation here..$^{37}$

17 I would argue that the interest of these letters lies more in what they suggest than in what they explicitly say or to put it differently in their subtext more than in their text. The first point to be noted is that the letters were all written without the slightest spelling or grammar mistake, which is rather surprising since the directors of the institution themselves deplored the fact that about two thirds of the women that entered the institution could not write. Should this be construed as some further evidence of the pedagogical success of the teachers of the institution or should it rather be analysed as the sign of some kind of editorial intrusion? The style, the structure and the internal organisation of these letters are so similar that one is entitled to think that they must have been carefully read, analysed, selected, censored, amended and edited before publication. These letters could thus be seen as the implementation of a practical exercise more than the expression of some genuine personal feelings. The letters were a form of discourse inserted into another larger and inherently different form of discourse; in fact, what we have here is a double level of discourse. The letters were indeed diverted from their primary function, the private sphere, and integrated 
into an official discourse aimed at the public sphere. First, the letters were obviously meant to demonstrate that the objective of the institution had been reached. The authors of the letters expressed themselves with great humility, showed that they understood that they had seriously sinned and committed themselves to leading a virtuous life. It might be interesting to point out that these letters were mentioned by one of the members of the select committee on the Contagious Diseases Act who indicated that the documents "[breathed] a great amount of piety and religious feeling". ${ }^{38}$ The letters also had another function: they helped to send a positive image of the Institution and thus encouraged the public to make donations. The institution was not self-supporting and it needed money from the public since the work of the inmates represented only two thirds of its total budget. The strategy of inserting former inmates' letters in the annual reports of the Institution apparently bore its fruit; the authors of the report of 1863 indeed remarked that

The generosity of the public has placed ample funds in your Directors' hands for their ordinary expenditure during the past year; and it has gratified them much to notice the continuance of that accession of new subscriptions of a smaller amount, which they take as an indication of an increasing interest in the work in which they are engaged. The continuance of former subscriptions from friends of the cause they thankfully regard as a proof of confidence in their administration. ${ }^{39}$

\section{Social control according to Michel Foucault}

To get a better understanding of the strategies of social control that were implemented by structures such as the Glasgow Magdalene Institution it seems necessary to refer to Michel Foucault's work and more particularly to his studies of the prison system and of the relationships between the notions of power, knowledge, and discourse. ${ }^{40}$ Let us start with the following quotation: "Hôpitaux, asiles, collèges, usines, ateliers avec leur discipline, et finalement, prisons, tout cela fait partie d'une espèce de grande forme sociale du pouvoir qui a été mise en place au début du XIXème siècle". ${ }^{41}$ Although the term "espèce" seems to be open to different possible interpretations, it appears that Michel Foucault clearly suggests that social control and power are interconnected concepts. Only those who detain the power can develop strategies aimed at subduing potentially destabilizing elements in society. Foucault stresses the fact that communication between police and medicine is absolutely essential. He adds that hospitals are invested with different missions, to cure, to redress, to correct and to control, which is exactly how the Glasgow Magdalene Institution saw its function.

19 Analysing Michel Foucault's theory Jean-Philippe Cazier has the following comment: “ Enfermer le délinquant, c'est d'abord l'inclure dans un réseau coercitif de surveillance et de contrôle qui l'individualise et le fixe pour l'assujettirit ${ }^{42}$." The notion of confinement is essential to an understanding of the process prostitutes were subjected to. In structures such as the Glasgow Magdalene Institution individuals were inserted in a strict organisation of time and space, leaving them a minimum amount of freedom and independence. Confinement became a means of acting not only on the bodies but also on the minds since one of the central purposes of the process was to produce subjects that would comply with a certain number of well established and clearly determined rules and norms. Foucault also uses the concept of "quadrillage", which, in a recent book devoted to some of the fundamental aspects of Foucault's work, has been described in the following terms: 
Le mot quadrillage contient en lui deux notions : celle d'encerclement, ou d'enfermement, et celle de gestion, de guidance de l'objet. Par le quadrillage l'objet du pouvoir est contrôlé et agencé. Le quadrillage appartient donc à un programme, il n'est ni spontané, ni improvisé. Ce programme du quadrillage se développe par un savoir, ou par une sélection du savoir, que détient le pouvoir. [...] Le pouvoir sélectionne le savoir, et ce qui est enseigné est d'abord une partie productive de ce savoir [...] Il y a donc par le savoir, un procédé d'enfermement de la pensée, un conditionnement de l'individu comme producteur, ou travailleur, et comme reproducteur d'un sens en cours. ${ }^{43}$

It seems to me that the polysemy of the French term cannot be easily rendered into English, the least unsatisfactory translation of "quadrillage" would probably be control, but the French term connotes regularity, method, coherence, efficiency, order, organisation, power and obviously control. All these terms could be used to describe the nature of the process put in place by structures such as the Glasgow Magdalene Institution. As Pierre Bourdieu has demonstrated, power can express itself without the use of physical force and can be transmuted in a symbolic form, and as such invested with a kind of legitimacy. ${ }^{44}$ What has to be noted here is that the type of power displayed by the Glasgow Magdalene Institution was not only symbolic, since the authorities could and did resort to punishment or violence. Yet, the letters published in the reports seem to suggest that the inmates, at least some of them, participated in their own subjection. The ultimate success of the process of rehabilitation could only be attained through the inmates' active complicity and their belief in the institution's legitimacy.

\section{Pierre Bourdieu's concept of habitus}

Here I would like to refer to the concept of habitus as developed by Pierre Bourdieu. For Bourdieu, the concept of habitus, which is produced socially and corresponds to the interiorisation or the incorporation of exteriority, designates a series of dispositions that lead the agent to behave and react in a certain way..$^{45}$ The concept is meant to refer primarily to those dispositions acquired during childhood that inevitably reflect the social conditions in which they have been acquired. What I am suggesting here is that this notion of habitus can be used to explore and assess the nature and the extent of the task undertaken by the directors of the Glasgow Magdalene Institution; indeed the Institution's main purpose consisted in trying to transform what I would call the original habitus of the inmates, an enormously complex task, since Bourdieu argues that the original dispositions are so deeply rooted in the body and in the mind that they endure all along the individual's existence. The letters published in the annual reports would tend to substantiate the idea that the process of transformation succeeded or to put it differently that the Institution managed to erase the past of these women and to replace it with a new set of beliefs and behaviours. Two essential questions need to be asked here: did the system work for all of these women and were they all ready to accept the place that had been chosen for them?

\section{Moral purification and social rehabilitation}

Several elements would seem to suggest that some of these women opposed or refused the processes of moral purification and social rehabilitation they were subjected to. 
The annual report of 1863 for example indicated that "if striking results were to be held as the measure of the value and efficiency of such an agency as the Magdalene Institution, those charged with its management might be discouraged when presenting their Annual Report". ${ }^{46}$ Furthermore, a close reading of the statistics provided by the Institution itself suggests that the system was far from being totally efficient. The report of 1878 indicated that:

It is shewn that of 294 young women who left during the year, 96, or nearly onethird, have been satisfactorily disposed of: that is to say, after having received the usual industrial and educational training, in most cases extending to two years, they have been restored to their friends, or have been placed in respectable situations. True, there are besides these a good many cases more or less disappointing. Some were passed on to other institutions more likely to benefit them, while others proved quite "unsuitable", or "left on their own accord", after having been only a short time, sometimes only a few days with us. ${ }^{47}$

At no time does the report explain the precise nature of what the institution calls " unsuitable" behaviour or provide any information about why some of the inmates decided to leave the institution. What these figures undoubtedly demonstrate is that any form of social control necessarily contains the possibility of resistance, unrest, opposition or even rebellion. One of the principal aims of the Glasgow System was to fight the "Great Social Evil" and to transform prostitutes into law-abiding and socially useful citizens. As the General Board of Directors of the Institution admitted in 1873, this aim had been only partly achieved and only in certain areas of the town of Glasgow:

In regard to repressive action it was stated that the central part of the city was almost entirely cleared of improper houses and that street solicitation was greatly lessened, but there was reason to fear that the outside districts and suburbs were in danger of being visited by the above evils unless precautions were used. ${ }^{48}$

\section{Conclusion}

Although the select committee on the contagious Diseases Act concluded that the Glasgow System had managed to fight prostitution efficiently,

"the case of Glasgow was especially relied upon as showing that without the exceptional legislation of the acts, prostitution might be greatly diminished and order and decency established in a large town, simply by means of stringent police interference", ${ }^{49}$

there can be no denying that some women refused to be "socially controlled" and to comply with the rules established by Victorian society; furthermore the "operation against the monster evil and the ravages of this terrible scourge", to quote the words used in the report of the Institution in $1862,{ }^{50}$ was a highly discriminatory process since a large number of prostitutes went on plying their trade at the periphery of the town in less respectable districts. Some of the women who went through the filter of the Magdalene Institution were passive and obedient subjects but evidence also suggests that others did refuse to adhere to the dominant patriarchal ideology of the time. The Institution's main purpose was to oblige the inmates to adopt the behaviour, beliefs, values and norms of the respectable part of society (or to put it in the Institution's own words, "to restore young women to lives of respectability" $\left.{ }^{51}\right)$, but the process, and I would like to end on that final remark, was also a source of potential instability and subversion. 


\section{BIBLIOGRAPHY}

Bourdieu, Pierre, Questions de Sociologie [1984] (Paris, Les Éditions de Minuit, 2002).

Bourdieu, Pierre, Langage et Pouvoir Symbolique [1991] (Paris, Seuil, 2001).

Bourdieu, Pierre, La Domination Masculine [1998] (Paris, Seuil, 2002).

Devine, Thomas Martin, The Scottish Nation 1700-2000, [1999] (Harmondsworth, Penguin, 2000).

Fisher, Trevor, Prostitution and the Victorians (Stroud, Sutton, 1997).

Foucault, Michel, Surveiller et punir (Paris, Gallimard, 1975).

Gordon, Eleanor, Breitenbach, Esther (eds.), The World is Ill Divided (Edinburgh, Edinburgh

University Press, 1990).

Glasgow Magdalene Institution, Annual Report [Glasgow, Mitchell Library], 1862, 1863, 1875, $1878,1884,1889$

Greg, William, The Great Sin of Great Cities (London, 1853).

Leclercq, Stéfan (ed.), Abécédaire de Michel Foucault (Mons, Sils Maria, 2004).

Parliamentary Papers, Report from the Select Committee on the Contagious Diseases Acts, [Edinburgh, National Library of Scotland] Vol. VIII, xiv, 1881.

Parliamentary Papers, Report from the Select Committee on the Contagious Diseases Acts, [Edinburgh, National Library of Scotland] vol. IX, civ, 1882.

Tait, William, Magdalenism, An Inquiry into the Extent, Causes and Consequences of Prostitution in Edinburgh (Edinburgh, 1840).

Trudgill, Eric, Madonnas and Magdalens: The Origins and Development of Victorian Sexual Attitudes (London, Heinemann, 1976).

Walkowitz, Judith, Prostitution and Victorian Society: Women, Class and the State (Cambridge, Cambridge University Press, 1980).

Wardlaw, Ralph, Lectures on Female Prostitution: its Nature, Effects, Guilt, Causes, and Remedy (Glasgow, 1842).

\section{NOTES}

1. In 2015 I was contacted by Jacques Leruez who asked me if I would be interested in giving a lecture on the Highland Clearances for the Association franco-écossaise. I gave that lecture in November 2016 at the Collège des Écossais in Paris. Jacques Leruez was very interested in the topic and more specifically in the various movements of resistance against the Highland Clearances that were most of the time led by women of the Highlands. We had a long conversation about the fact that it was the women of the Highlands and not the men who stood against the people who were in charge of evicting them. That's why I thought that an article dealing with another aspect of my research about gender issues, the social control implemented by the Glasgow authorities over prostitutes at the end of the nineteenth century, would have interested Jacques Leruez. 
2. Parliamentary Papers, Report from the Select Committee on the Contagious Diseases Acts, [Edinburgh, National Library of Scotland] vol. IX, civ, 1882 (hereafter Report, 1882), pp. 372-373.

3. Judith Walkowitz, Prostitution and Victorian Society: Women, Class and the State (Cambridge, Cambridge University Press, 1980), p. 32.

4. Ibid., p. 32.

5. See Eric Trudgill, Madonnas and Magdalens: The Origins and Development of Victorian Sexual Attitudes (London, Heinemann, 1976), p. 111 ; Trevor Fisher, Prostitution and the Victorians (Stroud, Sutton, 1997), p. 29; Judith Walkowitz, op. cit., p. 32.

6. Quoted in Linda Mahood, 'The Wages of Sin: Women, Work and Sexuality in the Nineteenth Century', pp. 29-48, in Eleanor Gordon and Esther Breitenbach (eds.), The World is Ill Divided (Edinburgh, Edinburgh University Press, 1990), p. 32.

7. William Tait, Magdalenism, An Inquiry into the Extent, Causes and Consequences of Prostitution in Edinburgh (Edinburgh, 1840), p. 1.

8. William Greg, The Great Sin of Great Cities (London, 1853), p. 11.

9. Ralph Wardlaw, Lectures on Female Prostitution: its Nature, Effects, Guilt, Causes, and Remedy (Glasgow, 1842), p. 43.

10. Two other laws were passed in 1866 and 1869.

11. Parliamentary Papers, Report from the Select Committee on the Contagious Diseases Acts, [Edinburgh, National Library of Scotland] Vol. VIII, xiv, 1881 (hereafter, Report, 1881), pp. 370-1.

12. Glasgow Magdalene Institution, Annual Report [Glasgow, Mitchell Library], (hereafter GMI, Report), 1862, p. 4.

13. Ibid.

14. Ibid.

15. GMI, Report, 1865, p. 11.

16. GMI, Report, 1863, p. 9.

17. GMI, Report, 1878, p. 9.

18. Some of the women spent less than two years in the institution. The report of 1865 indicates that a young woman left the institution after eight months only and that another was allowed to go back to her family after a year and a half. (GMI, Report, 1865, appendix A)

19. GMI, Report 1884, p. 15.

20. GMI, Report 1878, p. 14.

21. Ibid.

22. GMI, Report 1884, p. 13.

23. GMI, Report 1878, p. 14.

24. Ibid.

25. Ibid., p. 16.

26. GMI, Report 1889, p. 15.

27. GMI, Report, 1884, p. 15.

28. GMI, Report 1889, p. 12.

29. Thomas Martin Devine, The Scottish Nation 1700-2000, [1999] (Harmondsworth, Penguin, 2000), p. 364 .

30. Ibid., p. 30.

31. GMI, Report 1878, p. 14.

32. GMI, Report 1884, p. 15.

33. GMI, Report 1889, p. 13.

34. Ibid., p. 13.

35. GMI, Report, 1878, p. 15.

36. Ibid., p. 16.

37. GMI, Report, 1863, p. 14.

38. Report, 1881, question 7616 . 
39. GMI, Report, 1863, p. 8.

40. See Michel Foucault, Surveiller et punir (Paris, Gallimard, 1975).

41. Quoted in Stéfan Leclercq (ed.), Abécédaire de Michel Foucault (Mons, Sils Maria, 2004), p. 70. "Hospitals, asylums, factories, workshops with their discipline and finally prisons, all those places are part of a kind of big social structure of power that was put in place at the beginning of the nineteenth century."

42. Jean Philippe Cazier in Stéfan Leclercq (ed.), Abécédaire, p. 42. "Locking up offenders amounts to including them in a coercive network of surveillance and control that individualizes them and fixes them to bring them into subjection".

43. Stéfan Leclercq in Stéfan Leclercq (ed.), Abécédaire, pp. 152-153. "The term control contains two notions: first encircling or confinement and second management or guidance of objects. Thanks to control the object of power is controlled and ordered. The pattern belongs to a program; it is neither spontaneous nor improvised. This program of control develops through knowledge or through a selection of knowledge that is detained by power. [...] Power selects knowledge and what is taught is first a productive part of that knowledge [...] Thus through knowledge there is a process of confinement of thought, a conditioning of the individual as producer or worker and as reproducer of ongoing meaning."

44. See Pierre Bourdieu, Langage et Pouvoir Symbolique [1991] (Paris, Seuil, 2001).

45. See for example Pierre Bourdieu, Questions de Sociologie [1984 (Paris, Les Éditions de Minuit, 2002), pp. 133-137 ; Pierre Bourdieu, Langage, op. cit., pp. 22-27 ; Pierre Bourdieu, La Domination Masculine [1998] (Paris, Seuil, 2002), pp. 41-53.

46. GMI, Report 1863, p. 5.

47. GMI, Report, 1878, pp. 8-9.

48. GMI, Minutes of the General Board of Directors, 25 November 1873.

49. Report, 1882, p. lvii.

50. GMI, Report, 1862, pp. 5-6.

51. GMI, Report, 1878.

\section{ABSTRACTS}

The Contagious Diseases Acts that were passed in the 1860s to protect the army and the navy from venereal diseases represented the first real attempt of the British government to control and regulate prostitution in Great Britain. Although Glasgow was a garrison town, the laws were never applied there, as the town developed its own system to fight prostitution, the "Glasgow system". From the early 1870 s onwards three different institutions combined their efforts to try to eradicate the "great social evil": the police, the Lock Hospital, whose mission was to cure venereally diseased prostitutes, and the Magdalene Institution, where prostitutes underwent a process of moral purification.

This paper examines the role of the Glasgow Magdalene Institution as an instrument of social control and analyses the content and the function of the former inmates' letters that were published in the annual reports of the Magdalene Institution. These letters always gave a most positive image of the Institution and tended to demonstrate the efficiency of the system in terms of moral rehabilitation. But the organisation, the structure, the vocabulary as well as the content of the letters are so similar that they seem to testify more to the moral and didactic purpose of the directors of the institution than to the spontaneous and natural expression of their authors. 
These letters, which were diverted from their primary function - the private sphere -, fitted in the Glasgow Magdalene Institution's entire strategy that was primarily aimed at resocializing the women who had sinned and at imposing a moral model that actually stifled more than encouraged personal development.

Les lois sur les maladies contagieuses qui furent votées dans les années 1860 afin de protéger les soldats et les marins des maladies vénériennes constituent la première tentative de gouvernement britannique de contrôler et de réguler la prostitution en Grande-Bretagne. Bien que Glasgow fût une ville de garnison, les lois n'y furent jamais appliquées, la ville ayant mis au point son propre système pour lutter contre la prostitution, le «système de Glasgow ». À partir des années 1870, trois institutions joignirent leurs efforts pour éradiquer le " grand mal social ». : la police, l'hôpital Lock, qui avait pour mission de soigner les femmes atteintes de maladies vénériennes et la Magdalene Institution, chargée de la purification morale des prostituées.

Le présent article a comme ambition d'étudier le rôle de la Glasgow Magdalene Institution en tant qu'instrument de contrôle social et se propose d'analyser le contenu et la fonction des lettres de prostituées qui furent publiées dans les rapports annuels de l'Institution. Ces lettres avaient comme objectif de démontrer l'efficacité du système comme outil de réhabilitation morale. Cependant, l'organisation, la structure, le lexique utilisé de même que le contenu des lettres présentent de fortes similitudes, ce qui laisse à penser que ces lettres témoignent avant tout des intentions morales et didactiques des responsables de l'Institution davantage que d'une expression spontanée et naturelle de leurs auteurs. Ces lettres, détournées de leur fonction initiale, la sphère privée, s'intégraient dans la stratégie de l'Institution qui visait en premier lieu à resocialiser les femmes qui avaient péché et à imposer un modèle moral qui étouffait tout développement personnel.

\section{INDEX}

Mots-clés: Glasgow, Magdalene Institution, prostitution, Pierre Bourdieu, Michel Foucault Keywords: Glasgow, Magdalene Institution, prostitution, Pierre Bourdieu, Michel Foucault

\section{AUTHOR}

\section{CHRISTIAN AUER}

Professeur Émérite, Université de Strasbourg, EA 2325 SEARCH, Savoirs dans l'Espace Anglophone, Représentations, Culture, Histoire. Christian AUER, Agrégé de l'Université, Professeur Émérite à l'Université de Strasbourg, est spécialiste de civilisation britannique. Il travaille principalement sur les aspects économiques, politiques, sociaux et culturels de l'Ecosse au XIX siècle. Il est l'auteur de nombreux articles et de plusieurs ouvrages dont Scotland and the Scots 1707-2007 A Reader (Strasbourg, Presses Universitaires de Strasbourg, 2013) et Luttes et résistances des femmes écossaises, 1838-1915 (Paris, L'Harmattan, Collection des idées et des femmes, 2013). 